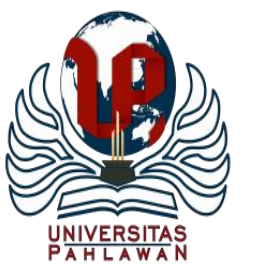

Jurnal Basicedu Volume 4 Nomor 4 Tahun 2020 Halm. 919 - 928

JURNAL BASICEDU

Research \& Learning in Elementary Education

https://jbasic.org/index.php/basicedu/index

\title{
Blended Learning Terhadap Hasil Belajar Di Era COVID-19: Pendekatan Meta-Analisis
}

\author{
Ayu Atika ${ }^{1}$, Amir Machmud ${ }^{2}$, Suwatno ${ }^{3}$ \\ Universitas Pendidikan Indonesia, Bandung, Indonesia ${ }^{1,2,3}$ \\ E-mail : ayuatika@upi.edu $\underline{\text { amirmachmud@upi.edu }}^{2} \underline{\text { suwatno@upi.edu }^{3}}$
}

\begin{abstract}
Abstrak
Penelitian ini mengkaji dari studi primer yang telah diteliti sebelumnya tentang blended learning terhadap hasil belajar. Hal ini menarik peneliti untuk mengkaji secara meta-analisis dengan 28 studi primer dari 40 studi sebab di era COVID-19 ini, pembelajaran secara tatap muka tidak mungkin dilaksanakan sehinggu perlu kombinasi pembelajaran secara online atau disebut blended learning. Hasil penelitian menunjukan bahwa terdapat pengaruh yang sangat signifikan karena korelasi rerata sebesar 1,63 yang kemudian kesalahan pengambilan sampel yang menunjukkan angka presentase yang kecil sebesar 12\%. Selanjutnya, dampak kesalahan pengukuran atau variasi reliabilitas dalam studi meta-analisis ini sebesar $1,4 \%$. Sehingga dapat dikatakan bahwa ada hubungan positif antara blended learning terhadap hasil belajar.
\end{abstract}

Kata kunci : blended learning, hasil belajar, COVID-19

\begin{abstract}
This study examines the previously agreed upon primary studies of Blended Learning on Learning Outcomes. This is interesting for researchers to study the meta-analysis with 28 primary studies from 40 reason studies in the covid-19 era, learning is not possible every week, it needs a combination of learning online or called Blended Learning. The results showed that there was a very significant difference due to a mean change of 1.63 which then took a sample that showed a small percentage of 12\%. Furthermore, the critical measurement error or reliability variation in a meta-analysis study was $1.4 \%$. Because it can be associated with a positive relationship between Blended Learning on Learning Outcomes.
\end{abstract}

Keywords: blended learning, learning outcomes, COVID-19

Copyright (C) 2020 Ayu Atika, Amir Machmud, Suwatno

Corresponding author :

Address : Bandung

ISSN 2580-3735 (Media Cetak)

Email : ayuatika@upi.edu

ISSN 2580-1147 (Media Online)

Phone : 081564714622

DOI:_https://doi.org/10.31004/basicedu.v4i4.488 


\section{LATAR BELAKANG}

Di era pandemik COVID-19 ini, semua masyarakat dianjurkan oleh pemerintah untuk tetap berdiam diri di rumah agar penyebaran virus dapat terkendali. Pembelajaran di sekolah pun terpaksa dialihkan di rumah mengingat sekolah di Indonesia yang memiliki 45,5 juta pelajar merupakan salah satu tempat rawan adanya penyebaran virus ini. Oleh karena itu, sekolah harus memiliki strategi pembelajaran agar tetap melaksanakan pembelajaran sesuai dengan kurikulum yang sudah ditetapkan.

Pembelajaran jarak jauh tetap harus dilaksanakan dengan berbagai solusi yang memang harus diputuskan oleh sekolah. Penggunaan pembelajaran online seperti Google Classroom, Edmodo, Schoology, Moodle, dan lainnya dapat dianggap menjadi solusi untuk saat ini. Sebelum adanya wabah ini pun sebetulnya sudah banyak guru yang menerapkannya. Penggunaan media tersebut harus dapat menjadi alat guru untuk tetap melaksanakan pembelajaran sesuai dengan kurikulum yang berlaku agar tujuan dalam pendidikan itu sendiri dapat terealisasi dengan baik.

Melihat bahwa pembelajaran yang telah dilaksanakan selama beberapa bulan di kelas dan saat ini menggunakan pembelajaran online, hal tersebut menandakan bahwa pembelajaran blended learning dapat diterapkan sebagai solusi. Namun, pembelajaran blended learning pun harus dapat menciptakan pembelajaran yang menyenangkan kemudian para peserta didik akan mendapatkan hasil belajar yang memuaskan meskipun hanya melalui pembelajaran online.
Menurut (Sanjaya, 2020) bahwa hasil belajar adalah suatu proses aktivitas mental seseorang dalam berinteraksi dengan lingkungannya sehingga menghasilkan perubahan tingkah laku yang bersifat positif baik perubahan dalam aspek pengetahuan, sikap, maupun psikomotor. Dikatakan positif, oleh karena perubahan perilaku itu bersifat adanya penambahan dari perilaku sebelumnya yang cenderung menetap (tahan lama dan tidak mudah dilupakan).

Pernyataan tersebut tentu menyiratkan bahwa hasil belajar dalam proses pembelajaran akan menentukan bagaimana ia akan berinteraksi dengan lingkungannya dengan baik atau buruk bergantung pada strategi belajar yang diciptakan oleh guru dalam proses pembelajaran. Strategi pembelajaran menggunakan blended learning yang telah dilakukan oleh guru selama pandemi COVID-19 ini dianggap dapat menciptakan hasil belajar yang memuaskan. Sebab, dikatakan oleh (Sjukur, 2013) terdapat perbedaan hasil belajar antara siswa yang diajarkan pembelajaran blended learning dibandingkan siswa yang diajarkan pembelajaran konvensional. Kemudian didukung oleh (Daulay, 2016) bahwa terdapat pengaruh yang signifikan hasil belajar siswa yang dibelajarkan dengan metode blended learning berbasis Edmodo dengan hasil belajar siswa yang dibelajarkan dengan metode pembelajaran langsung.

Oleh karena itu, peneliti tertarik ingin melihat apakah strategi pembelajaran blended learning yang menggabungkan metode 
pembelajaran tatap muka dan pembelajaran online dapat menciptakan hasil belajar yang baik.

\section{METODE}

Penelitian ini bermaksud untuk dapat mengetahui tentang pengaruh blended learning terhadap hasil belajar siswa dari beberapa hasil penelitian yang telah dilakukan dengan hipotesis sebagai berikut "ada hubungan positif blended learning terhadap hasil belajar siswa". Penelitan yang dilakukan ini menggunakan metode meta analisis. Menurut Glass (1981) bahwa meta analisis merupakan suatu analisis integratif sekunder dengan menerapkan prosedur statistik terhadap hasil-hasil pengujian hipotesis penelitian. Analisis sekunder itu merupakan analisis ulang (reanalysis) terhadap data untuk tujuan menjawab pertanyaan penelitian dengan teknik-teknik statistik yang lebih baik atau menjawab pertanyaan-pertanyaan baru dengan data lama yang dimiliki. Analisis sekunder merupakan suatu ciri-ciri penting terhadap riset dan kegiatan evaluasi.

Peneliti mencari, membaca, dan menganalisis penelitian-penelitian terdahulu terkait blended learning terhadap hasil belajar. Dalam penelitian ini mempergunakan pengambilan sampel data primer yang sudah digunakan pada penelitian-penelitian sebelumnya untuk dikaji lebih lanjut dan membandingkan dengan penelitian yang serupa lainnya. Ada 28 jurnal dari 45 jurnal yang terseleksi berdasarkan nilai t, F, d, atau r yang terdapat pada jurnal tersebut untuk dijadikan sebagai rujukan penelitian dimana memenuhi syarat penelitian meta-analisis yaitu terdapat nilai t, F, d, atau r. Kemudian 28 jurnal tersebut terdiri dari jurnal nasional yang merupakan terbitan tahun 2012 sampai dengan 2020.

\section{HASIL DAN PEMBAHASAN}

Dalam data studi primer yang telah dilakukan ditemukan adanya studi yang tidak ditemukan nilai $r$, akan tetapi hanya terdapat terdapat nilai t, d, dan F. Oleh karena itu, studi yang tidak terdapat nilai tersebut untuk ditransformasikan kedalam nilai t, F, d, dan $\mathrm{r}$ dengan menggunakan rumus (Hunter \& Schmidt, 2004) seperti yang terdapat pada tabel 1.

\section{Meta Analisis Metode Bare Bone : Koreksi Kesalahan Sampling}

Dibawah ini adalah tahapan metode meta analisis dari Bare Bone yang diungkapkan Hunter \& Schmidt (2004) yang bertujuan untuk dapat mengetahui koreksi kesalahan sampling yang terjadi dari penelitian yang telah dilakukan. Hasil analisis data nya adalah sebagai berikut:

\section{a. Menghitung Rerata Korelasi Populasi (rxy atau $\check{r}$ atau $\rho x y$ )}

Berikut ini merupakan proses penghitungan untuk mengetahui rerata korelasi populasi yang telah dikoreksi setelah data nilai transformasi t, f, d, dan r diketahui, yakni:

$$
\begin{gathered}
\rho x y=\frac{\sum\left(N_{i} r_{i}\right)}{\sum N_{i}} \\
\rho x y=\frac{854.29}{1956} \\
\rho x y=0.44
\end{gathered}
$$


Tabel 1

Hasil Tabel Meta Analisis

\begin{tabular}{|c|c|c|c|c|c|c|c|c|c|c|}
\hline Studi & $\mathbf{N}$ & $\mathbf{F}$ & $\mathbf{t}$ & $\mathbf{r}$ & $\mathbf{r x y}$ & $\begin{array}{l}\mathbf{N} x \\
\mathbf{r x y}\end{array}$ & $\begin{array}{c}\mathbf{r X Y} \\
-\breve{\mathbf{r}}\end{array}$ & $\begin{array}{l}(\mathbf{r X Y} \\
-\breve{\mathbf{r}}) 2\end{array}$ & $\begin{array}{l}\mathbf{N} \times \\
(\mathbf{r X Y} \\
-\check{\mathbf{r}}) 2\end{array}$ & (a) \\
\hline Studi 1 & 62 & 6.75 & 9.41 & 0.77 & 0.77 & 47.86 & 0.27 & 0.07 & 4.54 & 0.88 \\
\hline Studi 2 & 68 & 2.95 & 1.72 & 0.21 & 0.21 & 14.06 & -0.29 & 0.09 & 5.90 & 0.45 \\
\hline Studi 3 & 60 & 59.09 & 7.69 & 0.71 & 0.71 & 42.62 & 0.21 & 0.04 & 2.63 & 0.84 \\
\hline Studi 4 & 30 & 24.78 & 4.98 & 0.69 & 0.69 & 20.55 & 0.18 & 0.03 & 1.02 & 0.83 \\
\hline Studi 5 & 56 & 26.85 & 5.18 & 0.58 & 0.58 & 32.27 & 0.08 & 0.01 & 0.32 & 0.76 \\
\hline Studi 6 & 60 & 185.23 & 13.61 & 0.87 & 0.87 & 52.36 & 0.37 & 0.14 & 8.28 & 0.93 \\
\hline Studi 7 & 22 & 17.14 & 4.14 & 0.68 & 0.68 & 14.95 & 0.18 & 0.03 & 0.70 & 0.82 \\
\hline Studi 8 & 152 & 8.50 & 2.92 & 0.23 & 0.23 & 35.20 & -0.27 & 0.07 & 11.05 & 0.48 \\
\hline Studi 9 & 36 & 35.05 & 5.92 & 0.71 & 0.71 & 25.65 & 0.21 & 0.04 & 1.61 & 0.84 \\
\hline Studi 10 & 74 & 0.46 & 0.07 & 0.01 & 0.01 & 0.57 & -0.49 & 0.24 & 18.02 & 0.09 \\
\hline Studi 11 & 77 & 0.05 & 0.23 & 0.77 & 0.77 & 59.37 & 0.27 & 0.07 & 5.60 & 0.88 \\
\hline Studi 12 & 27 & 4.60 & 2.26 & 0.41 & 0.41 & 11.10 & -0.09 & 0.01 & 0.22 & 0.64 \\
\hline Studi 13 & 33 & 24.78 & 4.98 & 0.67 & 0.67 & 21.99 & 0.17 & 0.03 & 0.90 & 0.82 \\
\hline Studi 14 & 84 & 16.62 & 4.08 & 0.41 & 0.41 & 34.48 & -0.09 & 0.01 & 0.69 & 0.64 \\
\hline Studi 15 & 251 & 0.87 & 2.17 & 0.14 & 0.14 & 34.15 & -0.37 & 0.13 & 33.47 & 0.37 \\
\hline Studi 16 & 71 & 6.99 & 2.64 & 0.30 & 0.30 & 21.54 & -0.20 & 0.04 & 2.78 & 0.55 \\
\hline Studi 17 & 52 & 29.30 & 5.41 & 0.61 & 0.61 & 31.61 & 0.11 & 0.01 & 0.59 & 0.78 \\
\hline Studi 18 & 53 & 7.01 & 2.65 & 0.35 & 0.35 & 18.43 & -0.15 & 0.02 & 1.25 & 0.59 \\
\hline Studi 19 & 60 & 185.23 & 13.61 & 0.87 & 0.87 & 52.36 & 0.37 & 0.14 & 8.28 & 0.93 \\
\hline Studi 20 & 120 & 4.21 & 27.64 & 0.93 & 0.93 & 111.68 & 0.43 & 0.18 & 22.14 & 0.96 \\
\hline Studi 21 & 38 & 21.81 & 4.67 & 0.61 & 0.61 & 23.34 & 0.11 & 0.01 & 0.49 & 0.78 \\
\hline Studi 22 & 152 & 13.93 & 3.73 & 0.29 & 0.29 & 44.31 & -0.21 & 0.04 & 6.69 & 0.54 \\
\hline Studi 23 & 69 & 2.95 & 1.72 & 0.21 & 0.21 & 14.16 & -0.30 & 0.09 & 6.04 & 0.45 \\
\hline Studi 24 & 57 & 27.14 & 5.21 & 0.57 & 0.57 & 32.77 & 0.07 & 0.01 & 0.31 & 0.76 \\
\hline Studi 25 & 36 & 2.89 & 1.70 & 0.28 & 0.28 & 10.08 & -0.22 & 0.05 & 1.76 & 0.53 \\
\hline Studi 26 & 22 & 17.14 & 4.14 & 0.68 & 0.68 & 14.95 & 0.18 & 0.03 & 0.70 & 0.82 \\
\hline Studi 27 & 66 & 5.04 & 2.25 & 0.27 & 0.27 & 17.84 & -0.23 & 0.05 & 3.52 & 0.52 \\
\hline Studi 28 & 68 & 2.95 & 1.72 & 0.21 & 0.21 & 14.06 & -0.29 & 0.09 & 5.90 & 0.45 \\
\hline TOTAL & 1956 & 740.29 & 146.41 & 14.03 & 14.03 & 854.29 & 0.00 & 1.79 & 155.4 & 18.96 \\
\hline MEAN & 69.86 & 26.44 & 5.23 & 0.50 & 0.50 & 0.44 & 0.00 & 0.06 & 0.08 & 0.68 \\
\hline $\begin{array}{l}\text { STD } \\
\text { DEV }\end{array}$ & 48.34 & & & 0.26 & & & & & & 0.21 \\
\hline
\end{tabular}

Adapun hasil dari perhitungan diatas telah didapat hasil rerata korelasi populasi yang telah dikoreksi dengan jumlah sampel yaitu 0,44 . b. Menghitung varians rxy populasi $\left(\sigma^{2} r\right)$

Berikut ini merupakan proses perhitungan dari varians dari populasi setelah data nilai 
transformasi t, f, d, dan $\mathrm{r}$ diketahui adalah sebagai berikut:

$$
\begin{gathered}
\sigma^{2} r=\frac{\sum\left(N_{i}\left(r_{i}-\bar{r}\right)^{2}\right)}{\sum N_{i}} \\
\sigma^{2} r=\frac{155.4}{1956} \\
\sigma^{2} r=0.08
\end{gathered}
$$

Adapun hasil dari perhitungan diatas telah didapat hasil varians dari populasi yaitu 0,08 .

\section{c. Menghitung varians kesalahan pengambilan sampel}

Berikut ini merupakan proses perhitungan dari varians kesalahan pengambilan sampel setelah data nilai transformasi t, f, $d$, dan $r$ diketahui adalah sebagai berikut:

$$
\begin{gathered}
\sigma^{2} e=\left(1-\bar{r}^{2}\right)^{2} /(\bar{N}-1) \\
\sigma^{2} e=\left(1-0.44^{2}\right)^{2} /(69.86-1) \\
\sigma^{2} e=0,64 /(68.86) \\
\sigma^{2} e=0.0093
\end{gathered}
$$

Adapun hasil dari perhitungan diatas telah didapat hasil varians dari kesalahan pengambilan sampel yaitu 0,08 .

\section{d. Menghitung varians korelasi populasi yang} dikoreksi.

Berikut ini merupakan proses perhitungan dari varians korelasi populasi yang telah dikoreksi dimana nilai varians kesalahan pengambilan sampel sudah didapat dari hasil perhitungan diatas yaitu:

$$
\begin{gathered}
\sigma^{2} \rho=\sigma^{2} r-\sigma^{2} e \\
\sigma^{2} \rho=0.08-0.0093
\end{gathered}
$$

$$
\sigma^{2} \rho=0.0707
$$

Dari hasil perhitungan diatas nilai varians $r$ populasi di penelitian ini adalah sebesar 0.0707. Setelah itu, melihat $\sigma^{2} \rho$ yang telah didapat maka diperoleh hasil besaran Standar Deviasi (SD) $=\sqrt{ } \sigma 2 \rho=\sqrt{ } 0.0707=0.27$.

\section{Interval Kepercayaan}

Dari hasil perhitungan diatas yang dilakukan berdasarkan metode meta analisis yang merujuk pada teori dari Hunter dan Schmidt (2004) bahwa "Jika mean lebih dari dua SD lebih besar dari $0=$ hubungan yang dipertimbangkan selalu POSITIF". Oleh karena itu, dari penelitian yang telah dilakukan didapat hasil perbandingan Rerata Korelasi Populasi ( $\check{r}$ ) dengan Standar Deviasi (SD) yang dikoreksi sebesar $=0.44 / 0.27=1.63$.

Berdasarkan data diatas menandakan bahwa korelasi rerata didapat hasil 1.63 yang merupakan nilai lebih dari nilai 0. Maka hasil tersebut menunjukkan bahwa antara blended learning dan hasil belajar adalah nyata/positif ada. Kemudian hasil yang didapat dari metode perhitungan meta analisis tersebut juga menandakan bahwa penelitian ini mendukung atau menerima hipotesis tersebut.

Tanda positif yang terdapat dalam hasil perhitungan menandakan adanya hubungan antara variabel adalah positif, makna nya adalah semakin baik pelaksanaan blended learning maka semakin tinggi hasil belajar yang dapat dicapai, sebaliknya semakin rendah pelaksanaan blended learning akan meningkatkan hasil belajar yang dicapai.

\section{Dampak Kesalahan Pengambilan Sampel}


Berikut ini merupakan proses perhitungan dari dampak kesalahan dalam pengambilan sampel yaitu:

$$
\begin{gathered}
\left(\sigma^{2} e\right)=\frac{\left(\sigma^{2} \rho\right)}{\left(\sigma^{2} r\right)} \\
\left(\sigma^{2} e\right)=\frac{0.0707}{0.08} \\
\left(\sigma^{2} e\right)=0.88
\end{gathered}
$$

Adapun hasil dari proses perhitungan diatas menunjukan bahwa terdapat reliabilitas korelasi studi sebesar 0,13. Dari perolehan tersebut, dampak kesalahan pengambilan sampel sebesar $1-0,88=0.12$. Hal tersebut menunjukkan bahwa persentase kesalahan pengambilan sampling dalam penelitian sebesar $12 \%$.

\section{Koreksi Kesalahan Pengukuran}

Dalam penelitian meta analisis, dikatakan oleh Hunter \& Schmidt (2004) bahwa penggunaan dua artifak yaitu kesalahan pengambilan sampel dan koreksi kesalahan pengukuran. Oleh karena itu, perlu adanya proses pengukuran atau perhitungan untuk mengestimasi besaran dari kesalahan pengukuran yang didapat dari hasil transformasi nilai $\mathrm{t}$, $\mathrm{d}$, $\mathrm{f}$, dan $\mathrm{r}$ yang berupa reliabilitas alat ukur pada variabel masing-masing.

\section{e. Menghitung koreksi kesalahan pengukuran $\mathbf{Y}$}

Kesalahan pengukuran dalam sebuah penelitian umum terjadi, tingkat kesalahan pengukuran ini terukur oleh koefisien reliabilitas masing-masing studi penelitian. Semakin besar koefisien reliabilitas akan menghasilkan kesalahan pengukuran yang kecil. Oleh karena itu nilai korelasi populasi $(\bar{r})$ yang diperoleh pada tahapan analisis kedua perlu koreksi dengan melibatkan koefisen reliabilitas dalam hal ini pada variabel Y. rumus yang digunakan adalah

$$
\begin{gathered}
\bar{A}=A v e(a) \\
\bar{A}=0.68
\end{gathered}
$$

dengan:

$\bar{A}=$ rata-rata koreksi kesalahan pengukuran ( $a)=$ akar kuadrat koefisien reliabilitas $\operatorname{Ave}(a)=$ rata-rata $(a)$

\section{Menghitung Korelasi Populasi Yang Dikoreksi}

Selanjutnya adalah menghitung nilai korelasi populasi yang sebenarnya atau setelah dikoreksi, yaitu dengan menggunakan formula berikut (Hunter \& Schmid, 2004):

$$
\begin{gathered}
\rho=\operatorname{Ave}\left(\rho_{i}\right)=\frac{\operatorname{Ave}(\bar{r})}{\bar{A}} \\
\rho=\operatorname{Ave}\left(\rho_{i}\right)=\frac{0.44}{0.68} \\
\rho=\operatorname{Ave}\left(\rho_{i}\right)=0.65
\end{gathered}
$$

\section{Keterangan :}

Ave $r=$ rerata sesungguhnya dari korelasi rxy $\bar{A}=$ rerata gabungan $(a)$

Jadi korelasi populasi setelah dikoreksi relibilitasnya pada variable Independen dan dependen sebesar 0,65 .

\section{f. Menghitung Koefisien Kuadrat Variasi (V)}

Langkah berikutnya yaitu menghitung jumlah koefisien kuadrat variasi (V) menggunakan formula berikut (Hunter \& Schmid, 2004), yaitu: 


$$
\begin{gathered}
V=\frac{S D^{2}(a)}{A v e^{2}(a)} \\
V=\frac{0.044}{0.46} \\
V=0.095
\end{gathered}
$$

Selanjutnya dihitung varians yang diakibatkan variasi artefak, yaitu:

$$
\begin{gathered}
\sigma^{2} 2=\rho^{2} \bar{A}^{2} V \\
\sigma^{2} 2=(0.65)^{2} \times(0.68)^{2} \times 0.095 \\
\sigma^{2} 2=0.24 \times 0.46 \times 0.095 \\
\sigma^{2} 2=0.01
\end{gathered}
$$

Varians korelasi populasi yang dikoreksi adalah sebagai berikut:

$$
\begin{gathered}
\operatorname{Var}(\rho)=\frac{\left[\operatorname{Var}\left(\rho_{x y}\right)-\rho^{2} \bar{A}^{2} V\right]}{\bar{A}^{2}} \\
\operatorname{Var}(\rho)=\frac{[0.08-0.01]}{(0.68)^{2}} \\
\operatorname{Var}(\rho)=\frac{0.07}{0.46} \\
\operatorname{Var}(\rho)=015
\end{gathered}
$$

Tahap berikutnya yaitu menghitung nilai SD (Standar Deviasi) melalui perhitungan berikut ini:

$$
\begin{gathered}
S D=\sqrt{\operatorname{Var}(\rho)} \\
S D=\sqrt{0.15} \\
S D=0.38
\end{gathered}
$$

Dari perhitungan diatas diperoleh hasil bahwa estimasi $r$ populasi adalah korelasi populasi yang telah dikoreksi dari kesalahan pengukuran $(\rho)$ yaitu 0.65 dan Standar Deviasi (SD) sebesar 0.38.

\section{Interval kepercayaan}

Dari hasil perhitungan diatas yang dilakukan berdasarkan metode meta analisis yang merujuk pada teori dari Hunter dan Schmidt (2004) bahwa
"Jika mean lebih dari dua SD lebih besar dari $0=$ hubungan yang dipertimbangkan selalu POSITIF". Oleh karena itu, dari penelitian yang telah dilakukan didapat hasil perbandingan Rerata Korelasi Populasi (ř $)$ dengan Standar Deviasi (SD) yang dikoreksi sebesar $=0.65 / 0.38=1.71$.

Berdasarkan data diatas menandakan bahwa korelasi rerata didapat hasil 1.71 yang merupakan nilai lebih dari nilai 0 . Maka hasil tersebut menunjukkan bahwa antara blended learning dan hasil belajar adalah nyata/positif ada. Kemudian hasil yang didapat dari metode perhitungan meta analisis tersebut juga menandakan bahwa penelitian ini mendukung atau menerima hipotesis tersebut.

Tanda positif yang terdapat dalam hasil perhitungan menandakan adanya hubungan antara variabel adalah positif, makna nya adalah semakin baik pelaksanaan blended learning maka semakin tinggi hasil belajar yang dapat dicapai, sebaliknya semakin rendah pelaksanaan blended learning akan meningkatkan hasil belajar yang dicapai.

\section{Dampak Kesalahan Pengukuran atau Variasi Reliabilitas}

Berikut ini merupakan proses perhitungan dari dampak kesalahan pengukuran atau variasi reliabilitas yaitu:

$$
\begin{gathered}
\frac{\overline{\rho^{2} A^{2}} V}{\overline{\sigma^{2}(\rho x y)}} \\
\frac{0.01}{0.68}
\end{gathered}
$$

$$
\frac{0.01}{0.68}=0.014 \times 100 \%=1,4 \%
$$


Dari proses perhitungan diatas didapat hasil besaran dampak kesalahan pengukuran atau variasi reliabilitas dari hasil perhitungan koreksi kesalahan pengukuran yang dilakukan menggunakan metode meta-analisis yaitu $1,4 \%$.

Perolehan hasil perhitungan yang menggunakan penelitian meta analisis tersebut yang dilakukan dengan menggunakan koreksi dua artifak yaitu: koreksi terhadap kesalahan pengambilan sampling (sampling error) dan koreksi terhadap kesalahan pengukuran (error measurement) dari 28 penelitian yang telah dilakukan tentang blended learning terhadap hasil belajar menandakan adanya suatu hubungan antara blended learning dan hasil belajar adalah nyata/positif ada.

Hal tersebut juga menunjukan bahwa adanya arah hubungan kedua variabel adalah positif, dapat dilihat melalui rerata korelasi populasi setelah dikoreksi dengan jumlah sampel ( $r X Y$ atau $\check{r}$ atau $\rho X Y$ ) yaitu sebesar 0,44 (Interval kepercayaan pada koreksi pengambilan sampel yaitu sebesar 1,63; dan Interval kepercayaan pada koreksi pengukuran sebesar 1,71. Maknanya adalah semakin tinggi kemampuan untuk menggunakan blended learning maka semakin tinggi hasil belajarnya, sebaliknya semakin rendah pelaksanaan blended learning maka semakin rendah pula hasil belajar. Seorang pengajar yang memiliki kemampuan model blended learning tidak akan membiarkan siswa nya tidak belajar dengan kondisi COVID-19 ini, justru akan semakin membuat hasil belajar siswa semakin tinggi dalam belajar.

\section{PEMBAHASAN}

Blended learning dapat meningkatkan hasil belajar sama dengan atau lebih tinggi dari pelajar yang belajar secara konvensional atau sepenuhnya online, meskipun tingkat keberhasilan bervariasi antara disiplin ilmu (Heinze, 2008). Hal tersebut menunjukkan dukungannya bahwa apa yang telah diteliti tentang blended learning terhadap hasil belajar dikatakan cukup berhasil. Gambaran tersebut cukup membuat guru/dosen terus memberikan pengajaran melalui online karena dianggap dapat menciptakan hasil belajar yang memuaskan meskipun sedang dalam keadaan pandemi COVID-19 ini disamping hasil belajar yang memang baru menekankan pada aspek pemahaman. Tetapi hal tersebut jauh lebih penting sebagai solusi dalam menjaga nyawa para peserta didik dan mencegah penyebaran virus mematikan tersebut agar dapat terkendali dengan baik.

Meskipun banyak pertentangan dari beberapa kalangan khususnya orang tua, penggunaan blended learning dengan menggunakan metode e-learning atau kelas maya seperti platform Google Classroom, Edmodo, dan Schoology ternyata memiliki dampak positif terhadap hasil belajar anak. Dan tidak menutup kemungkinan pula memang ada juga dampak negatif dari penggunaan metode tersebut. Namun, studi yang telah dilakukan dari 28 penelitian yang dikaji menunjukkan adanya hal yang membawa positif. Apalagi di masa pandemi ini yang mengharuskan anak-anak untuk berdiam diri di rumah..

Mengkaji beberapa teori tentang pemahaman diatas sebagai bagian dari hasil belajar 
yang diciptakan oleh proses pembelajaran blended learning menandakan bahwa dengan hanya menggunakan pembelajaran tersebut seorang peserta didik dapat berada pada tahap pemahaman yang hanya berupa pemahaman terjemahan, pemahaman penafsiran, bahkan dapat mencapai tahap pemahaman ekstrapolasi dimana dapat meningkatkan persepsi terhadap kejadian/ masalah nyata di lingkungan sekitarnya.

Dampak kesalahan pengambilan sampel yang telah dianalisis menunjukan bahwa reliabilitas korelasi studi yaitu sebesar 0,88, maka didapat hasil dari dampak kesalahan pengambilan sampel yaitu sebesar $1-0,88=0.12$. Dapat ditarik kesimpulan juga bahwa persentase kesalahan pengambilan sampling dari penelitian yang telah dilakukan adalah sebesar $12 \%$. Melihat presentase tersebut, menunjukan bahwa kesalahan pengambilan sampling dari populasi studi primer yang telah diteliti dalam studi meta-analisis ini memiliki presentase yang kecil.

Kemudian dampak kesalahan pengukuran atau variasi reliabilitas yang telah dianalisis menunjukan bahwa besarnya dampak kesalahan pengukuran atau variasi reliabilitas pada hasil koreksi kesalahan pengukuran dalam studi metaanalisis ini sebesar 1,4\%. Sehingga dapat dikatakan bahwa kesalahan pengurukan variasi reliabilitas pada penelitian dari studi primer yang telah dilakukan memiliki presentase yang kecil.

\section{KESIMPULAN}

Hasil penelitian yang telah dilakukan menggunakan studi meta-analisis dari studi primer menunjukan adanya dukungan terhadap hipotesis pada studi primer yang telah diteliti sebelumnya yang menyatakan bahwa blended learning berkorelasi positif terhadap hasil belajar yang artinya semakin tinggi pelaksanaan blended learning maka semakin tinggi pula hasil belajar yang didapat. Kemudian terdapat pengaruh yang sangat signifikan karena korelasi rerata sebesar 1,63 yang kemudian kesalahan pengambilan sampel yang menunjukan angka presentase yang kecil sebesar $12 \%$. Selanjutnya, dampak kesalahan pengukuran atau variasi reliabilitas dalam studi meta-analisis ini sebesar 1,4\%. Sehingga dapat dikatakan bahwa kesalahan pengurukan sampling dan kesalahan variasi reliabilitas pada penelitian dari 28 studi primer yang telah dilakukan memiliki presentase yang kecil.

\section{DAFTAR PUSTAKA}

Daulay, U. A. (2016). Pengaruh Blended Learning Berbasis Edmodo Dan Motivasi Belajar Terhadap Hasil Belajar IPA Biologi Dan Retensi Siswa Pada Sistem Peredaran Darah Manusia Di Kelas VIII SMP N 5 Medan [Universitas Negeri Medan]. http://digilib.unimed.ac.id/id/eprint/19997

Heinze, A. (2008). Blended learning: An interpretive action research study. [University of Salford, UK]. http://usir.salford.ac.uk/1653/1/\%0AHeinze _2008_blended_elearning.\%0Apdf

Sanjaya, W. (2020). Kurikulum dan pembelajaran: Teori dan praktik pengembangan kurikulum tingkat satuan pendidikan (KTSP). Kencana Prenada Media Group.

Sjukur, S. B. (2013). Pengaruh blended learning terhadap motivasi belajar dan hasil belajar siswa di tingkat SMK. Jurnal Pendidikan Vokasi, 2(3), 368-378. https://doi.org/10.21831/jpv.v2i3.1043 
928 Blended Learning Terhadap Hasil Belajar Di Era COVID-19: Pendekatan Meta-Analisis - Ayu Atika, Amir Machmud, Suwatno

DOI:_https://doi.org/10.31004/basicedu.v4i4.488

Kholifah dan Asto. (2016). Pengaruh Model Pembelajaran Blended Learning Terhadap Hasil Belajar Dan Motivasi Belajar Siswa Kelas XI TEI Pada Mata Pelajaran Komunikasi Data Dan Interface Di SMK Negeri 1 Jetis Mojokerto. Surabaya : Jurnal Pendidikan Teknik Elektro UNESA. Volume 05 Nomor 03 Tahun 2016, 975 - 982

Munzadi, Moh. (2018). Pengaruh Blended Learning Berbasis Rotation Model Terhadap Motivasi Dan Hasil Belajar Geografi Siswa MA Matholiul Anwar Lamongan. Jurnal Pendidikan Geografi Undiksha Volume 6, Number 3, November 2018, pp. 125-132

Ibrahim, Nurdin. (2012). Meningkatkan Hasil Belajar Matematika Dengan Blended Learning Dan Motivasi Berprestasi Siswa. Jurnal Perspektif Ilmu Pendidikan - Vol. 26 Th. XVII Oktober 2012.

Setyoko, Indriaty. (2018). Penerapan Pembelajaran Problem Based Learning Berbasis Blended Learning terhadap Hasil Belajar Kognitif dan Motivasi Mahasiswa. Jurnal Pendidikan Biologi 7 (3) (2018) 157 166 